\title{
Assessing the Impact of Service-Learning in a Criminal Justice Statistics Class
}

\section{Kimberley Schanz}

Stockton University, USA

Kaela Giles

Stockton University, USA

\section{Recommended Citation}

Schanz, K., \& Giles, K. (2021). Assessing the impact of service-learning in a criminal justice statistics class. International Journal of Research on Service-Learning and Community Engagement, 9(1), Article 4. 


\section{Assessing the Impact of Service- Learning in a Criminal Justice Statistics Class}

\author{
Kimberley Schanz and Kaela Giles
}

Service-learning is a pedagogical strategy that has been incorporated into classrooms in the social sciences increasingly in recent years. However, there has been less incorporation of servicelearning into nontraditional courses such as statistics, despite its potentially large beneficial impacts on the students in statistics courses. This study used a quasi-experimental design and a mixed-methods analysis to determine the impact of service-learning on criminal justice students' attitudes and outcomes in the context of a statistics course over four semesters. The impact was difficult to measure quantitatively; the qualitative findings suggested that students benefited in terms of their positive attitudes toward statistics and the overall learning outcomes of the course. The findings have implications for students' future careers within the criminal justice field.

Keywords: criminal justice, future careers, service-learning, statistics

\section{Evaluación del índice de impacto del aprendizaje-servicio en una clase de estadística de Criminología}

\author{
Kimberley Schanz y Kaela Giles
}

El aprendizaje-servicio es una estrategia pedagógica que se ha incorporado progresivamente en las clases de ciencias sociales en los últimos años. No obstante, su presencia curricular es menos frecuente en cursos no tradicionales como la estadística, a pesar de su potencial para impactar positivamente a sus estudiantes. El presente estudio emplea un diseño cuasiexperimental y un análisis de métodos mixtos para determinar el impacto del componente de aprendizaje-servicio en las actitudes y en los resultados de aprendizaje de los estudiantes de Criminología a lo largo de cuatro semestres. Si bien el índice de impacto resulta difícil de medir cuantitativamente, el análisis cualitativo sugiere que a los estudiantes les influyó favorablemente dicho componente en relación a las actitudes positivas y los resultados de aprendizaje del curso. Las conclusiones del estudio tienen relación directa con la futura trayectoria profesional de los estudiantes de Criminología.

Palabras clave: criminología, trayectoria profesional, aprendizaje-servicio, estadística

Editors' Note: Translation by Maria Fernandez Cifuentes

Department of Languages, Literatures, and Cultures University of North Florida, USA 
Service-learning has become a frequent addition to many courses in service-based majors such as social work, political science, and criminal justice. This article is the product of a study that aimed to understand the impact of service-learning projects in a nontraditional service-learning class: a statistics class. Specifically, the study examined the perceptions criminal justice students held about statistics and its use within the criminal justice system.

Whereas research has shown that students in the social sciences are resistant to statistics courses (Gredig \& Bartelsen-Raemy, 2018), this resistance is pronounced in criminal justice (Griffith et al., 2012; Krimmel \& Tartaro, 1999). This resistance may be explained by a lack of awareness of how statistical knowledge would be of benefit to the student (Ciarocco et al., 2013; Earley, 2014; Murtonen, 2015). However, the history of criminal justice education and the ethos of the real-world application of criminal justice research has led to an emphasis on using evidence-based practices, among other notions (Finckenauer, 2005). It is for this reason that statistics is needed within criminal justice curricula, despite students' preferences. This article examines hypotheses focused on completion of a service-learning experience and changes in students' negative attitudes toward statistics in criminal justice.

\section{Service-Learning}

Service-learning pedagogy aims to connect coursework with a real-world experience, thereby allowing participant to apply academic knowledge in a community-based setting (Fertman, 1994). Service-learning is more than just volunteering or interning; its goal is to connect course content with active service in the community (Trail Ross, 2012). This is generally done by (1) connecting the course objectives to the community service, (2) providing a learning experience for all parties involved (especially students and community partners), (3) responding to the needs of community partners, and (4) reflecting on the servicelearning experience (Trail Ross, 2012).

Service-learning has been shown to have a positive impact on students' academic outcomes. For example, improvement in course averages and graduation rates have been associated with the completion of service-learning projects (Gutierrez et al., 2012; Mungo, 2017; Penn, 2003; Warren, 2012). Beyond academic success, service-learning provides exposure to professionally relevant skills. Through servicelearning, students looking to pursue a career in service-based fields like criminal justice can reflect on what will likely be regular aspects of their professional lives.

Whereas students report that they generally have a positive experience with service-learning projects (Burke \& Bush, 2013; Conover, 2015; Swanson et al., 1997; Vigorita, 2002), research has shown that service-learning particularly impacts professional development by fostering positive growth in specific professional skills, such as communication and teamwork (Conover, 2015; Doehler, 2018; HirschingerBlank et al., 2009; Penn, 2003; Phelps, 2012), as well as general life skills, including personal insight, cognitive development, and civic responsibility (Gutierrez et al., 2012; Lersch, 1997; Penn, 2003; Yorio \& Ye, 2012). Service-learning also provides an outlet for students to apply course material and concepts to real-world scenarios, as they would in their community-based careers (Burke \& Bush, 2013; Gutierrez et al., 2012; Hirschinger-Blank et al., 2009; McClam et al., 2008; Nordmoe, 2007; Sessa et al., 2009).

Finally, service-learning has additionally been shown to highlight potential career options for students and aid in their career decision-making (Gutierrez et al, 2012; Hiedemann \& Jones, 2010; HirschingerBlank et al., 2009; Lersch, 1997; McClam et al., 2008; Nordmoe, 2007; Vigorita, 2002). This is especially true regarding critical reflection: service-learning provides a concrete, guided opportunity for students to learn how to reflect, thereby turning their real-world experiences into learning experiences (Blackwell et al., 2001; Jarvis, 1992). Service-learning, therefore, provides a unique opportunity for students in general, but specifically criminal justice students, to be exposed to different community members and to develop their reflective capacities for service to the community (Hirschinger-Blank et al., 2009; Lersch, 1997; McClam et al., 2008; Vigorita, 2002). For this reason, this study uses service-learning to assess attitude changes through reflective activities. 


\section{Negative Attitudes and Applicability of Statistics}

The goal of any statistics course is usually twofold: to teach the mathematics of statistics so students can perform it and to help students understand the interpretation of the mathematics so they can apply it in the "real world." In fact, the emphasis on the real-world applicability and use statistics has been endorsed as necessary to statistical education by many leaders of the American Statistical Association (Doehler, 2018). This emphasis is particularly relevant to criminal justice statistics courses, as the discipline's goal is to use statistics to determine evidence-based practices and policies. However, as mentioned earlier, researchers have noted resistance to the study of statistics, specifically among criminal justice majors. For instance, in one study, criminal justice students were more likely than business and psychology students to have negative attitudes toward statistics (Griffith et al., 2012). In this case, the criminal justice students with negative attitudes toward statistics most frequently felt that it was difficult (88\%), that it would not be used in their career (80\%), and/or that they had a dislike for mathematics (74\%) (Griffith et al., 2012).

Student resistance to statistics in social sciences in general and in criminal justice specifically has been explained, in part, as a (mis)perception that statistical knowledge is irrelevant and/or unnecessary for future practice-based careers (Ciarocco et al., 2013; Earley, 2014; Murtonen, 2015). However, research has shown that the understanding of the applicability and use of statistics is essential to most disciplines, especially because quantitative data have become more available, accessible, and used in recent years (Carver et al., 2016). Research has also shown that an effective way for students to learn about the applicability and use of statistics is to use it themselves (Doehler, 2018). As a result, a criminal justice course on statistics that requires students to engage in service-learning as part of a statistics project may demonstrate the importance of statistics and, in the process, reduce student resistance (Doehler, 2018).

Further, research has found that students have confirmed the value of statistics-based projects via service-learning in helping them understand how statistics can solve real-life problems (Nordmoe, 2007; Root \& Thorme, 2001). According to Nordmoe (2007), the vast majority of psychology and life-science students reported that their statistical service-learning experience helped them understand how problems could be solved using statistics. In the Root and Thorme's (2001) study, students who learned elementary college-level statistics specifically stated that the service-learning project using statistics helped them understand the importance of their statistics class to their discipline. Additionally, service-learning has been shown to adjust students' resistance toward statistics (Evangelopoulos et al., 2003; Hiedemann \& Jones, 2010). Business students involved in a statistics-relevant service-learning project were less likely to agree that statistics was not necessary in their discipline (Hiedemann \& Jones, 2010). In a separate study, business students also reported that the statistics course was significantly more useful when service-learning was incorporated into it (Evangelopoulos et al., 2003). While this research does not survey criminal justice students specifically, it certainly does suggest that the incorporation of a statistics-based service-learning project into a criminal justice statistics class may address both the applicability of statistics to the real world and students' resistance to the course content itself.

\section{Purpose of Study}

The purpose of this study — which was approved by the university's Institutional Review Board — was to explore whether attitudes about statistics, as well as performance on student learning outcomes, improved among criminal justice students who completed service-learning projects, as compared to those who did not. We hypothesized that, after participating in a service-learning project as part of the course, most students should not only have a better understanding of coursework and its benefits but also a changed perspective regarding the usefulness of statistics in criminal justice. We also expected that students would have a predominantly positive experience with the service-learning project itself. This study will determine whether students originally understood the value of a statistics course, whether that improved as a result of the service-learning project, and whether students reported a better understanding of the coursework as well as a changed perspective regarding the usefulness of statistics in criminal justice and the criminal justice system itself. 


\section{Method}

This study used a quasi-experimental design to determine the impact of service-learning on students' attitudes toward statistics. As explained below, data were generated by survey responses and reflection assignments.

\section{Participants}

Evaluation responses and assignments were collected from 139 students enrolled in undergraduate-level statistics classes taught by the first author in the Fall 2018, Spring 2019, Fall 2019, and Fall 2020 semesters at a small, public university in the Northeast. Due to COVID-19-related course changes at mid-semester, data were not collected for the study during Spring 2020. Students taking the course in Fall 2020 served as a control group, as the service-learning project was not conducted (also due to COVID-19 relatedrestrictions). Of the 139 students surveyed in the four semesters, 33 did not consent to have their responses used as part of the research. As a result, the final sample for this study consisted of 106 students.

Demographics of the sample are detailed in Table 1. Most of the students surveyed identified as female $(55.7 \%)$, were non-transfer students $(53.8 \%)$, and were fulltime undergraduate students $(96.2 \%)$. The mean GPA of the students surveyed was $3.28(S D=0.47)$. The most common career goal stated was Law Enforcement (39.6\%), with Other (17\%) and Forensic Science-Related (14.2\%) as the next most common. The overwhelming majority of students were criminal justice majors; over the four semesters, only four students were majoring in another social science (psychology and social work). There were no non-social sciences majors in any of the classes.

\section{Table 1}

Sample Demographics

\begin{tabular}{lccc}
\hline Demographic & $\begin{array}{c}\text { Total Sample } \\
\text { Percent }(\mathrm{N})\end{array}$ & $\begin{array}{c}\text { Experimental Group } \\
\text { Percent (N) }\end{array}$ & $\begin{array}{c}\text { Control Group } \\
\text { Percent (N) }\end{array}$ \\
\hline Gender & & & \\
Male & $55.7(59)$ & $43.4(36)$ & $65.2(12)$ \\
Female & $44.3(47)$ & $56.6(47)$ & $47.8(11)$ \\
& & & \\
Types of Student & & & \\
Non-transfer & $53.8(57)$ & $50.6(42)$ & $65.2(15)$ \\
Transfer & $46.2(49)$ & $49.4(41)$ & $34.8(8)$ \\
Fulltime & $96.2(102)$ & $96.4(80)$ & $95.7(22)$ \\
Parttime & $3.8(4)$ & $3.6(3)$ & $4.3(1)$ \\
Career Goal & & & \\
Law Enforcement & $39.6(42)$ & $39.8(33)$ & $39.1(9)$ \\
Other & $17(18)$ & $15.7(13)$ & $21.7(5)$ \\
Forensic Science-Related & $14.2(15)$ & $16.9(14)$ & $4.3(1)$ \\
Forensic Psychology-Related & $12.3(13)$ & $8.4(7)$ & $26.1(6)$ \\
Lawyer/Judge & $6.6(7)$ & $7.2(6)$ & $4.3(1)$ \\
Probation/Parole & $6.6(7)$ & $7.2(6)$ & $4.3(1)$ \\
Institutional Corrections & $0.9(1)$ & $1.2(1)$ & $0(0)$ \\
Unanswered & $2.8(3)$ & $3.6(3)$ & $0(0)$ \\
& & & \\
\hline
\end{tabular}




\section{Assessment Methods}

Students were assessed in three ways during the semester in which they were enrolled in Statistics for Criminal Justice: surveys at the start (i.e., a pretest) and at the end (i.e., a posttest) of each semester, and a reflection homework assignment.

\section{Pretest Assessment}

The pretest assessment consisted, in part, of questions already used in the Criminal Justice Program to assess student learning outcomes for statistics as a core course. Questions addressing the service-learning project were added to the end of the departmental assessment instrument. The 13 service-learning-relevant statements addressed students' perceptions of statistics in their career expectations, the role of service agencies, and the role of statistics in the criminal justice system overall. These topics were chosen to assess what students (mis)perceptions were of the applicability and use of statistics within the criminal justice discipline. Students were asked to select their level of agreement with each statement on a Likert scale of 1 (strongly disagree) to 5 (strongly agree) to each of the 13 statements (see Appendix A for the full list of statements). Six of these statements were reverse coded in the analyses. There were no qualitative prompts in the pretest assessment.

\section{Posttest Assessment}

The post-test assessment consisted of the same 13 statements in the pretest assessment and 10 additional statements. Of the 10 additional statements, seven addressed the students' individual experience in the service-learning project and used the same Likert scale used in the pretest assessment (see Appendix A). The remaining three additional statements were open-ended statements soliciting more nuanced information about the students' service-learning experience. (The purpose of these statements was to solicit reflective feedback from students. Eight of these statements (six from the pretest and two of the added statements) were reverse coded for analysis.

\section{Reflection Homework Assignment}

Research has shown that reflection is critical to the goals and outcomes of service-learning (Trail Ross, 2012). Therefore, students were required to complete structured reflection as part of their service-learning project. Reflection assignments were submitted approximately one week after students completing their service-learning project. The reflection directed students to discuss their experience with the servicelearning project and to relate it to course content (see Appendix B).

All assignments were graded as pass/fail; if the student turned in a relevant reflection, they were awarded all the points for the assignment. This was done to (a) encourage candidness by students and (b) to prevent bias into the analysis. The researchers wanted to ensure that, if students were truly learning the applicability and use of statistics as a result of the service-learning project, they were the ones to identify that connection. The researchers did not want the students to just "tell the professor what he/she wanted to hear." This is a very conservative approach to qualitative analysis, but the researchers preferred to be conservative rather than report potentially biased findings.

Each assignment submission was coded for thematic responses by the second author, a graduate assistant with no connection to the classes. The themes were determined based on commonalities in the assignments regarding the students' experiences with the service-learning engagement; they were not chosen a priori. This coding procedure allowed for all reported experiences to be considered as potential outcomes of the service-learning experience — not just those the authors would have expected.

\section{Procedure}

At the start of each semester and before the start of the second class session, all students completed the pretest assessment via the university's learning management system. Within the first two weeks of class, 
the Fall 2018, Spring 2019, and Fall 2019 students were introduced to the requirements of the servicelearning project, which involved a service-learning engagement with an external agency and a campusbased statistics lab. The service-learning engagement required students, in three separate groups throughout the semester, to interact with a service agency in a nearby city, collecting data on its constituents. All groups were accompanied by the lead researcher (first author) for their community-based engagement. The service agency partner for this project ran a community program aiming to assist formerly incarcerated individuals (specifically facing the issue of homelessness) trying to reintegrate into society. As such, the project directly addressed a population and issue relevant for criminal justice majors.

The tasks that students undertook during their service-learning engagement generally had one goal: to assist the agency in collecting data on their constituents' needs to be analyzed later by the students in the campus-based statistics lab. However, the location/context in which the students did so varied across semesters. The first two semesters' (Fall 2018 and Spring 2019) students assisted the agency by collecting data at an outreach event aimed at clearing outstanding warrants. In the third semester (Fall 2019), some students collected data at the outreach event while others did the same at their office location. Regardless of location, students were directly interacting with a population that, as criminal justice majors aiming to work in criminal justice system-based careers, they would likely encounter as professionals in the future. After taking part in the service-learning engagement, students submitted the reflection assignment within a week.

The statistics lab activity took place in the last week of the semester, during a regular class period, when the students analyzed the data they collected and presented the results to the agency. Typically, this consisted of a detailed analysis of the descriptive statistics as well as an analysis and description of the results from a one-way ANOVA. This was a graded component of the class; students could not opt out.

At the end of the semester, immediately preceding the final exam, all students completed the posttest assessment. The students in the Fall 2020 semester, serving as the control group, did not have a servicelearning project and therefore participated in only the pre- and post-test assessments. Student responses were not analyzed until the semester was over and final grades were submitted. This prevented bias in the study.

\section{Results}

The resulting data were analyzed both quantitatively and qualitatively to determine whether students originally understood the value of a statistics course, whether that improved as a result of the servicelearning project, and whether students reported a better understanding of the coursework as well as a changed perspective regarding the usefulness of statistics in criminal justice and the criminal justice system. Overall, the impact of service-learning was most evident in the students' qualitative responses about what they perceived to be benefits of the service-learning experience.

\section{Quantitative Analysis}

\section{Overall Attitudes Toward Statistics}

To determine students' initial attitudes regarding the value of the statistics class, the authors examined the means of the attitude survey from the beginning of each semester (i.e., pretest scores). Overall mean scores of the 13-question pretest survey (see Appendix A) showed a moderate level of agreement at the start of the class with means varying between 3.57 and $4.64(M=3.99, S D=0.29$; see Table 2 for all pre- and posttest assessment means). However, the lowest-scoring questions, as predicted, were the statistics-related questions $(M=3.88, S D=0.22)$, with the lowest agreement scores generated by the statements "Statistics will be helpful to me in my future career" $(M=3.63, S D=1.05)$ and "I would be at a disadvantage in the job market without statistics knowledge" $(M=3.57, S D=0.97)$. This confirms the finding of past research that students are inherently less aware of the value of statistics in their future careers (Ciarocco et al., 2013; Earley, 2014; Murtonen, 2015). 
Table 2

Means for Pre- and Post-Test Assessments

\begin{tabular}{|c|c|c|}
\hline Statement & Pretest Mean $(S D)$ & Posttest Mean (SD) \\
\hline $\begin{array}{l}\text { The criminal justice system needs to operate on } \\
\text { evidence-based policies. }\end{array}$ & $4.00(0.781)$ & $4.04(0.716)$ \\
\hline $\begin{array}{l}\text { I can use statistics to address a criminal justice } \\
\text { problem. }\end{array}$ & $4.09(0.735)$ & $3.94(1.050)$ \\
\hline $\begin{array}{l}\text { Statistics will not be helpful to me in my future } \\
\text { career.* }\end{array}$ & $3.63(1.05)$ & $3.55(1.126)$ \\
\hline $\begin{array}{l}\text { Statistics are key to conducting research on the } \\
\text { criminal justice system. }\end{array}$ & $4.22(0.676)$ & $4.09(0.845)$ \\
\hline $\begin{array}{l}\text { Statistics knowledge has no value in my future } \\
\text { career.* }\end{array}$ & $3.80(0.999)$ & $3.63(1.107)$ \\
\hline $\begin{array}{l}\text { This class will provide/provided knowledge that I } \\
\text { will use in the future. }\end{array}$ & $3.80(0.825)$ & $3.81(1.034)$ \\
\hline $\begin{array}{l}\text { Statistics are not necessary to determine } \\
\text { effectiveness of policy changes.* }\end{array}$ & $3.90(0.883)$ & $3.75(1.024)$ \\
\hline $\begin{array}{l}\text { I would be at a disadvantage in the job market } \\
\text { without statistics knowledge. }\end{array}$ & $3.57(0.966)$ & $3.36(1.071)$ \\
\hline Mean for Statistics-Relevant Statements & $3.88(0.222)$ & $3.77(0.251)$ \\
\hline $\begin{array}{l}\text { There is more to the criminal justice system than } \\
\text { law enforcement and corrections. }\end{array}$ & $4.64(0.652)$ & $4.64(0.650)$ \\
\hline $\begin{array}{l}\text { The only career options for Criminal Justice majors } \\
\text { are in law enforcement.* }\end{array}$ & $4.33(0.983)$ & $4.39(0.972)$ \\
\hline $\begin{array}{l}\text { Criminal justice majors would make good } \\
\text { contributors to service agencies. }\end{array}$ & $4.06(0.754)$ & $4.12(0.689)$ \\
\hline $\begin{array}{l}\text { Service agencies are not part of the criminal justice } \\
\text { system.* }\end{array}$ & $3.85(0.830)$ & $3.78(0.986)$ \\
\hline $\begin{array}{l}\text { Service agencies have no impact on the criminal } \\
\text { justice system.* }\end{array}$ & $4.06(0.903)$ & $4.09(0.867)$ \\
\hline Mean for Career-Related Statements & $3.99(0.840)$ & $3.94(0.347)$ \\
\hline $\begin{array}{l}\text { I enjoyed engaging in a community project in this } \\
\text { class. }\end{array}$ & & $4.09(0.885)$ \\
\hline $\begin{array}{l}\text { I do not feel that my work in this class has made an } \\
\text { impact on the community project.* }\end{array}$ & & $3.49(0.978)$ \\
\hline $\begin{array}{l}\text { I took pride in my work on the community project } \\
\text { from this class. }\end{array}$ & & $3.81(0.854)$ \\
\hline $\begin{array}{l}\text { I do not think it is important to use my knowledge } \\
\text { to assist my community.* }\end{array}$ & & $3.95(1.044)$ \\
\hline $\begin{array}{l}\text { I feel that the community project helped me learn } \\
\text { the class material easier. }\end{array}$ & & $3.40(1.085)$ \\
\hline $\begin{array}{l}\text { The class material was more concrete because of } \\
\text { the community project. }\end{array}$ & & $3.32(0.993)$ \\
\hline $\begin{array}{l}\text { I feel that my time working on the community } \\
\text { project was worthwhile. }\end{array}$ & & $3.82(1.041)$ \\
\hline $\begin{array}{l}\text { Mean for Service-Learning Engagement } \\
\text { Statements }\end{array}$ & & $3.70(0.294)$ \\
\hline
\end{tabular}


To determine whether those attitudes changed over the course of the semester, change scores were calculated by subtracting the pretest summary scores from the posttest summary scores for each student (see Table 3 for means of total scores). Change scores were very small across the four semesters $(M=$ $0.73, S D=6.24$ ), indicating that as a collective, students did not quantifiably shift their attitudes. Due to the high variability in the responses, however, it is clear that some individual students did express larger attitudinal changes. When assessing the statistics-related responses specifically, the trend was similar. The mean change scores from the start to the end of the semester were also small, with high variability $(M=$ $0.82, S D=4.79)$. This implies that, from the beginning to the end of the class, students generally had similar levels of agreement on their attitudes related to statistics, although there were some individual students who reported larger shifts.

Table 3

Means of Total Scores for Pre- and Post-Assessments

\begin{tabular}{lcccc}
\hline Total Assessment Score & Pre Mean & Pre $\boldsymbol{S D}$ & Post Mean & Post $\boldsymbol{S D}$ \\
\hline Overall & & & & \\
$\quad$ Fall 2018 & 49.08 & 7.523 & 49.50 & 7.940 \\
$\quad$ Spring 2019 & 52.12 & 6.214 & 50.21 & 7.924 \\
Fall 2019 & 52.46 & 5.155 & 53.46 & 7.685 \\
Fall 2020 & 53.130 & 5.303 & 50.957 & 6.819 \\
Statistics-Related Questions & & & & \\
$\quad$ Fall 2018 & 29.00 & 4.520 & 29.33 & 5.289 \\
Spring 2019 & 31.21 & 4.948 & 29.24 & 5.995 \\
Fall 2019 & 31.62 & 3.732 & 32.153 & 5.228 \\
Fall 2020 & 31.57 & 4.273 & 29.65 & 5.556 \\
\hline
\end{tabular}

\section{Impact of the service-learning experience}

To determine whether the presence of service-learning impacted students' attitudes, the data were separated by semester and categorized as belonging to an experimental (Fall 2018, Spring 2019, and Fall 2019) or control (Fall 2020) semester. A one-way ANOVA showed no significant differences in change scores $(t(104)=1.260, p>.05)$. When looking at the statistics-related questions, the trend was similar; there were no significant differences in change scores on the statistics-related questions, $(t(104)=1.239, p>.05)$. Based on the pre- and post-test assessments, there does not seem to be quantitative evidence that students' attitudes about statistics shifted throughout the semester as a result of their service-learning experiences.

\section{Attitudes to the Service-Learning Experience}

To determine whether the students enjoyed the service-learning experience and whether they thought it impacted their learning, 7 posttest statements (see Appendix A, Service-Learning Experience) for Fall 2018, Spring 2019, and Fall 2019 were examined. In terms of students' reported enjoyment, as expected, students generally agreed that they enjoyed the service-learning experience and felt it was important for students to participate $(M=3.70, S D=0.29)$. This confirms a past research finding that service-learning is a positive experience for students (Burke \& Bush, 2013; Vigorita, 2002; Conover, 2015; Swanson et al., 1997). When it came to the impact of the service-learning experience on content learning, students generally agreed that the experience assisted them $(M=3.40, S D=1.09)$. This supports a finding from past research that service-learning is associated with improved academic outcomes (Gutierrez et al., 2012; Penn, 2003; Warren, 2012). 


\section{Summary}

While there was no quantitative evidence for a service-learning-dependent attitudinal shift among the students, their attitudes may be more nuanced than can be accurately measured by a quantitative scale. As a result, qualitative analyses were conducted on the open-ended posttest statements and the reflections to determine whether a change in perspective toward statistics could be detected.

\section{Qualitative Analysis}

The qualitative data were collected from the posttests as well as from reflections on the service-learning experience to gain a richer understanding of whether the project helped to improve students' perceptions of statistics. Since the quantitative analysis showed that there were no significant differences between responses across the semesters, the qualitative responses were analyzed as a single group.

\section{Impact of the Service-Learning Experience}

To assess the impact of the service-learning experience, students were asked to report what benefits, if any, they personally experienced as a result of the service-learning project (see Table 4). As Table 4 indicates, most students noted that learning the criminal justice system through real-world examples was the most beneficial aspect $(\mathrm{N}=25)$. Students also frequently expressed the sentiment that, as a result of their service-learning experience, they changed their perspectives or had a unique experience $(\mathrm{N}=11)$. This also confirms the added benefits of service-learning for criminal justice majors: an opportunity to see what a future career may look like, and thereby disconfirm previously held beliefs about the population they might serve. About a third of the students reported that the service-learning experience helped with classwork $(\mathrm{N}=5)$ and demonstrated the importance of statistics/data $(\mathrm{N}=4)$. This addresses the lack of quantitative results by showing that students' attitudes toward statistics changed as a result of their servicelearning experience. This also potentially explains the high variance found in the quantitative data: some (not all) of the students recognized the academic benefits of service-learning by acknowledging that the experience increased their perceptions of statistics and their ability to conduct statistics.

\section{Table 4}

Responses to Question About Benefits of Participation in Community Project

\begin{tabular}{lc}
\hline Response Theme & Frequency (N) \\
\hline Learning the criminal justice system through real-world examples & 25 \\
Opportunity to engage in community service & 13 \\
Changed my perspective or provided a unique experience & 11 \\
Helped with classwork/statistics & 9 \\
Showing people that others care about them & 6 \\
Get to know the local area/community & 1 \\
Not answered/Not Applicable & 18 \\
\hline
\end{tabular}

Homework response trends generally followed a similar pattern. In terms of the students' knowledge regarding the use and applicability of statistics, 19 respondents referenced helping [the service agency] with data collection/analysis and 13 respondents referenced helping [the service agency] on-site as benefits gained from their participation service-learning. This highlights that, because of the service-learning project, students became very aware of their impact as community data collectors and analysts. As one student stated, 
I also believe that our analyses on the data will be really helpful to the organization because it will allow them to see what services are needed the most by the people who need the help. And with that information, they can grow and expand the organization to better suit the needs of the people in the city.

Another student echoed this sentiment and connected it to the direct (and intended) outcomes of the statistics-based service-learning project for the agency:

Our collaboration is helping the people we interacted with and [the service agency] because it gives them statistics on where people are coming to this service. For example, through our data, we learned that most of the people who attend these events are from [local county]; so, people are not traveling too far to access these services. The purpose our results serve is letting [the service agency] know where they should offer their services so the most people are able to get the help that they need.

\section{Attitudes to the Service-Learning Experience}

To determine whether the students enjoyed the service-learning experience and whether they thought it impacted their learning, students were asked what they enjoyed the most about the experience and how it was relevant to their future careers. Cumulatively, as can be seen in Table 5, most students enjoyed aspects of interacting and talking with people $(\mathrm{N}=31)$. The other common features of the project that students enjoyed the most were meeting workers and seeing the program $(\mathrm{N}=22)$, learning and seeing the system $(\mathrm{N}=15)$, and helping people $(\mathrm{N}=11)$. This confirms the quantitative findings that, overall, students had a positive experience with service-learning. Students also confirmed, as demonstrated in past research, that they enjoyed gaining exposure to the people they may work with in their future careers.

\section{Table 5}

Responses to Question About Part of Community Project Found Most Enjoyable

$\begin{array}{ll}\text { Response Theme } & \text { Frequency }(\mathbf{N})\end{array}$

Interacting and talking with people

Meeting workers and seeing the service programs

Helping people

Learning and seeing the system

Seeing the city and its community

The service agency itself

The professor

Learning how to use Narcan

Not answered/Not Applicable

In the homework responses, as shown in Table 6,16 students reported feeling that the project did help decide/learn skills for their future careers. Many used the phrase "eye-opening experience" in their 
reflections to describe their service-learning experience. One student specifically reported on how the experience informed the necessary skills she would need for her future career:

Something that I will take with me after attending this event is keeping in mind that a lot of people need some sort of help. So, when I become a police officer, I would do my job but be more of a community officer, the type that helps out and provides advice and guidance instead of being a robo-cop.

Table 6

Benefits of Community Project as Described in Reflections

\begin{tabular}{lc}
\hline Response Theme & Frequency (N) \\
\hline Ability to talk to/interact with people & 36 \\
Engaged in real-world experiences & 31 \\
Learned about the system and [the service agency] interactions & 29 \\
Helped those who were struggling & 23 \\
Helping [the service agency] with data collection and analysis & 19 \\
Helped to decide on and learn skills for a future career & 16 \\
Able to help [the service agency] on site & 13 \\
\hline
\end{tabular}

Therefore, as also shown in Table 7, not only were students able to see how statistics could be used in the criminal justice system but were also able to see how the service-learning project could inform their future careers.

\section{Table 7}

What Students Learned Relative to Their Future Careers as Described in Reflections

\begin{tabular}{lc}
\hline Response Theme & Frequency (N) \\
\hline Important to give people another chance in life & 14 \\
Important to provide a safe space with needed services to help people & 13 \\
Need to change perceptions about help seeking & 12 \\
Court responses to issues are highly sought after & 11 \\
Transportation is key to those seeking help & 4 \\
$\begin{array}{l}\text { Important to have a diverse staff and knowledge of a diverse community to be } \\
\text { able to adequately help those in need } \\
\text { Programs that aim to assist those in needs to build trust with their clients }\end{array}$ & 3 \\
\hline
\end{tabular}


The last question asked what students would change about the service-learning project. Table 8 indicates that most students answered nothing/not applicable $(\mathrm{N}=35)$. This generally confirms the expectations and quantitative findings that the service-learning experience was positive for students. Those who would change a facet of their participation in the project indicated the need to be more engaged/handson $(\mathrm{N}=23)$, go more often/have more time $(\mathrm{N}=6)$, and learn more before/ask more questions $(\mathrm{N}=5)$. This provided additional insight into the students' experiences. Not only did students report quantitatively and qualitatively a positive experience with service-learning; they also separately and spontaneously expressed a desire for it to be more meaningful, either by engaging in it more often or having the opportunity to engage in the experience more fully.

\section{Table 8}

Responses to Question About What Students Would Change About Community Project Participation

\begin{tabular}{lc}
\hline Response Theme & Frequency (N) \\
\hline Nothing & 35 \\
Be more engaged/hands-on & 23 \\
Go more often/have more time & 6 \\
Learn more before/ask more questions & 5 \\
Not have to do it & 5 \\
Not answered/Not Applicable & 12 \\
\hline
\end{tabular}

\section{Summary}

Whereas the quantitative data did not show a shift in perspective regarding the usefulness of statistics in the criminal justice system as a result of service-learning, the qualitative data provided some nuanced evidence that some students acknowledged how service-learning enhanced their understanding of statistics and its applicability to their future careers. Additionally, evidence was found that students were very aware of how the service-learning experience itself helped to prepare them, in skills and knowledge, for their future careers in the criminal justice system. Overall, students benefited from the service-learning experience.

\section{Discussion}

This study aimed to examine how service-learning impacts both students' content understanding of statistics and its applicability to their future careers. Prior research has shown that social science students, and particularly criminal justice students, tend to have negative opinions about statistics. However, in the field of criminal justice, there is a reliance on the determination and availability of evidence-based practices to build policy reforms. Therefore, students must understand how statistics apply to the criminal justice system and its operations. With this in mind, using pre- and posttest assessments and reflections, data on student perspectives and opinions were collected over the course of three semesters (and one control semester).

This study did provide evidence that service-learning impacted both the students' understanding of statistics and its applicability. When looking at the quantitative pre- and posttest statements that specifically addressed the usefulness of statistics to the criminal justice system, we found that students generally agreed that the service-learning experience did assist them in their learning. This provided some preliminary, if very general, evidence that including service-learning to a statistics class enhanced student learning 
outcomes. However, when examining the qualitative responses from students, those preliminary findings were amplified. More than half of the students noted that the service-learning project helped with classwork and enhanced their understanding of the importance of statistics to the criminal justice system, confirming past research that service-learning can positively impact learning outcomes (Conover, 2015; Currie-Mueller \& Littlefield, 2018; Doehler, 2018; Nordmoe, 2007; Phelps, 2012; Root \& Thorme, 2001). This was a slight majority of the responses., however. Further, they were spontaneous (i.e., not specifically prompted), suggesting that, even without prompting, students recognized how the service-learning project highlighted the applicability and use of statistics in the criminal justice. Additionally, about half of the responding students reported that service-learning did change their perspectives and provide them a unique experience.

Therefore, this study provides a significant amount of qualitative evidence to support the use of servicelearning in statistics classes. By providing the opportunity for students to engage in statistics within the context of the criminal justice system, they were able to concretely understand how statistics were applicable and used to improve an already existing process, thereby achieving a main learning outcome of the course.

There was also evidence supporting the positive impact that service-learning had on informing students' future careers. In their qualitative responses, students frequently reported that they learned more about the criminal justice system and the people it serves. Because they were doing so through real-world experiences provided by service-learning, this confirmed the effects of service-learning discussed in previous research (Burke \& Bush, 2013; Gutierrez et al., 2012; Hirschinger-Blank et al., 2009; McClam et al., 2008; Nordmoe, 2007; Sessa et al., 2009). Students, as stated above, also frequently reported changes in their perspectives, including their perspectives of the system and/or the people it serves.

The service-learning experience may have either reinforced or helped the students hone professional skills, gain insight into what their careers may look like, and may also have helped them decide on future careers, further confirming previous research findings on these effects (Conover, 2015; Doehler, 2018; Gutierrez et al, 2012; Hiedemann \& Jones, 2010; Hirschinger-Blank et al., 2009; Lersch, 1997; McClam et al., 2008; Nordmoe, 2007; Penn, 2003; Phelps, 2012; Vigorita, 2002). These findings suggest that criminal justice students specifically would benefit, in terms of learning and of their future, from service-learning in the curriculum. Through service-learning, they can learn about the community in which they will serve and interact, and they will be able to sharpen the skills needed to do so successfully.

There was also a large amount of evidence that, in general, the students enjoyed the service-learning aspect of the class and valued its inclusion in the curriculum. An analysis of the responses to the posttest statements indicated a high level of enjoyment; the mean response for that statement was among the highest in the posttest assessment. In their qualitative responses, students had the highest variation of responses to the enjoyment question, and most students additionally noted that they would not change the servicelearning experience. For those who would change the experience, they generally opted only to enhance the experience: to engage more in the experience and to have more time in the experience itself. This reinforces the literature showing the positive benefits of service-learning to students in general (Burke \& Bush, 2013; Conover, 2015; Swanson et al., 1997; Vigorita, 2002).

The presence of high levels of enjoyment in the service-learning experience is particularly important for criminal justice students. As part of the statistics class, the students engaged in a service-learning opportunity that was designed to share a fair number of similarities with their potential careers. If they enjoyed the experience as students, they will likely also enjoy similar experiences when encountered as part of their future careers. This may help students make more informed career choices within the criminal justice field and/or staving off attrition in the field due to unrealistic expectations. This may also counter the propensity for burnout in the criminal justice professions by encouraging them to seek out positive experiences within the field instead of leaving the field entirely.

In addition, the reflective skills learned via service-learning have been suggested to be key to effective and accurate policing (Christopher, 2015). As a result, these students, particularly the large number interested in law enforcement, may also have increased the likelihood of being successful in their future careers. 


\section{Limitations}

There are a few limitations to this study. First, while the authors actively chose to be less prescriptive in their prompts eliciting feedback from the students, there is the possibility that, should students have been prompted to discuss how the service-learning experience enhanced their learning and understanding, more students would have discussed that relationship. Second, while some students reported qualitatively that their perspectives had changed as a result of the service-learning experience, they were not specific regarding which perspectives of theirs changed. It is possible, therefore, that they were referring to their perspectives on statistics, but they also could have been referring to their perspectives about the criminal justice system. Again, had we specifically prompted students to discuss the impact their service-learning experiences in this class had on their understanding of statistics, this likely would have been elucidated. Lastly, we previously argued that the lack of quantifiable change in attitude shifts may be due to the lack of nuance captured by the agreement scale we used. Had we used a more extensive scale ( $0-7$ or even $0-$ 10 ), we may have been able to detect small-scale quantitative changes. Also, attitude change has previously been shown to be slight, especially in the face of previously existing contrary attitudes (Festinger \& Carlsmith, 1959); so, the lack of available gradation may have prevented students from accurately reporting their attitudinal change.

\section{Future Research}

Future research on this topic should include specific questions regarding professional skills gained from service-learning and the perceived applicability of those skills to the future careers of criminal justice students. This would be particularly interesting to follow longitudinally to determine whether students engaging in service-learning in college actually use those highlighted skills in their later careers. Also, future research should incorporate more direct measurements of attitudinal change to determine whether a change in perspectives relevant to statistics can be detected in criminal justice students.

\section{References}

Blackwell, A., Bowes, L., Harvey, L., Hesketh, A. J., \& Knight, P. T. (2001). Transforming work experience in higher education. British Educational Research Journal, 27(3), 269-285. https://doi.org/10.1080/01411920120048304

Burke, A. S., \& Bush, M. D. (2013). Service learning and criminal justice: An exploratory study of student perceptions. Educational Review, 65(1), 56-69. https://doi.org/10.1080/00131911.2011.638138

Carver, R., Everson, M., Gabrosek, J., Horton, N., Lock, R., Mocko, M., Rossman, A., Rowell, G. H., Velleman, P., Witmer, J., \& Wood., B. (2016). Guidelines for assessment and instruction in statistics education (GAISE) college report. American Statistical Association. http://www.amstat.org/asa/files/pdfs/GAISE/GaiseCollege_Full.pdf

Christopher, S. (2015). The police service can be a critical reflective practice ... if it wants. Policing: $A$ Journal of Policy and Practice, 9(4), 326-339. https://doi.org/10.1093/police/pav007

Ciarocco, N. J., Lewandowski, G. W., Jr., \& Van Volkom, M. (2013). The impact of a multifaceted approach to teaching research methods on students' attitudes. Teaching of Psychology, 40(1), 20 25. https://doi.org/10.1177/0098628312465859

Conover, T. E. (2015). Integrating community-based research into a criminal justice capstone course. Journal of Criminal Justice Education, 26(4), 408-422. https://doi.org/10.1080/10511253.2015.1049631 
Currie-Mueller, J. L., \& Littlefield, R. S. (2018). Embracing service-learning opportunities: Student perceptions of service-learning as an aid to effectively learn course material. Journal of the Scholarship of Teaching and Learning, 18(1), 25-42. https://doi.org/10.14434/josotl.v18i1.21356

Doehler, K. (2018). Successful service-learning for statistics students studying survey sampling. Statistics Education Research Journal, 17(2), 82-103.

Earley, M. A. (2014). A synthesis of the literature on research methods education. Teaching in Higher Education, 19(3), 242-253. https://doi.org/10.1080/13562517.2013.860105

Evangelopoulos, N., Sidorova, A., \& Riolli, L. (2003). Can service-learning help students appreciate an unpopular course?: A theoretical framework. Michigan Journal of Community Service Learning, 9(2), 15-24. http://hdl.handle.net/2027/spo.3239521.0009.202

Fertman, C. I. (1994). Service learning for all students. Phi Delta Kappa Educational Foundation.

Festinger, L., \& Carlsmith, J. M. (1959). Cognitive consequences of forced compliance. Journal of Abnormal and Social Psychology, 58, 203-210.

Finckenauer, J. O. (2005). The quest for quality in criminal justice education. Justice Quarterly, 22(4), 413-426. https://doi.org/10.1080/07418820500364635

Gredig, D., \& Bartelsen-Raemy, A. (2018). Exploring social work students' attitudes toward research courses: Predictors of interest in research-related courses among first year students enrolled in a bachelor's programme in Switzerland. Social Work Education, 37(2), 190-208. https://doi.org/10.1080/02615479.2017.1389880

Griffith, J. D., Adams, L. T., Gu, L. L., Hart, C. L., \& Nicholas-Whitehead, P. (2012). Students' attitudes toward statistics across the disciplines: A mixed-methods approach. Statistics Education Research Journal, 11(2), 45-56.

Gutierrez, R. S., Reeves-Gutierrez, D., \& Helms, R. (2012). Service learning and criminal justice students: An assessment of the effects of co-curricular pedagogy on graduation rates. Journal of Criminal Justice Education, 23(3), 356-380. https://doi.org/10.1080/10511253.2011.590514

Hiedemann, B., \& Jones, S. M. (2010). Learning statistics at the farmers market? A comparison of academic service learning and case studies in an introductory statistics course. Journal of Statistics Education, 18(3), 1-21. https://doi.org/10.1080/10691898.2010.11889584

Hirschinger-Blank, N. B., Simons, L., \& Kenyon, A. (2009). An evaluation of a service-learning model for criminal justice undergraduate students. Journal of Experiential Education, 32(1), 61-78. https://doi.org/10.1177/105382590903200106

Jarvis, P. (1992). Reflective practice and nursing. Nurse Education Today, 12(3), 174-181. https://doi.org/10.1016/0260-6917(92)90059-W

Krimmel, J. T., \& Tartaro, C. (1999). Career choices and characteristics of criminal justice undergraduates. Journal of Criminal Justice Education, 10(2), 277-289. https://doi.org/10.1080/10511259900084591

Lersch, K. M. (1997). Integrating service learning in undergraduate criminal justice courses:

Bringing academics to life. Journal of Criminal Justice Education, 8(2), 253-261. https://doi.org/10.1080/10511259700086341 
McClam, T., Diambra, J. F., Burton, B., Fuss, A., \& Fudge, D. L. (2008). An analysis of a servicelearning project: Students' expectations, concerns, and reflections. Journal of Experiential Education, 30(3), 236-249. https://doi.org/10.1177/105382590703000304

Mungo, M. H. (2017). Closing the gap: Can service learning enhance retention, graduation, and GPAs of students of color? Michigan Journal of Community Service Learning, 23(2), 42-52.

Murtonen, M. (2015). University students' understanding of the concepts empirical, theoretical, qualitative and quantitative research. Teaching in Higher Education, 20(7), 684-698. https://doi.org/10.1080/13562517.2015.1072152

Nordmoe, E. D. (2007). Service-learning in introductory statistics at Kalamazoo College. Journal of Statistics Education, 15(2), 1-6. https://doi.org/10.1080/10691898.2007.11889466

Penn, E. B. (2003). Service-learning: A tool to enhance criminal justice. Journal of Criminal Justice Education, 14(2), 371-383. https://doi.org/10.1080/10511250300085851

Phelps, A. L. (2012). Stepping from service-learning to service-learning pedagogy. Journal of Statistics Education, 20(3), 1-22. https://doi.org/10.1080/10691898.2012.11889649

Root, R., \& Thorme, T. (2001). Community-based projects in applied statistics: Using service-learning to enhance student understanding. The American Statistician, 55(4), 326-331. https://doi.org/10.1198/000313001753272295

Sessa, V. I., Matos, C., \& Hopkins, C. A. (2009). Evaluating a college leadership course: What do students learn in a leadership course with a service-learning component and how deeply do they learn it? Journal of Leadership Education, 7(3), 167-200.

Swanson, C., King, K., \& Wolbert, N. (1997). Mentoring juveniles in adult jail: An example of service learning. Journal of Criminal Justice Education, 8(2), 263-271. https://doi.org/10.1080/10511259700086351

Trail Ross, M. E. (2012). Linking classroom learning to the community through service learning. Journal of Community Health Nursing, 29(1), 53-60. https://doi.org/10.1080/07370016.2012.645746

Vigorita, M. S. (2002). Planning and implementing a criminal justice course with university students and youthful offenders. Journal of Criminal Justice Education, 13(2), 403-432. https://doi.org/10.1080/10511250200085551

Warren, J. L. (2012). Does service-learning increase student learning? A meta-analysis. Michigan Journal of Community Service Learning, 18(2), 56-61.

Wells, M. (2006). Making statistics "real" for social work students. Journal of Social Work Education, 42(2), 397-404.

Yorio, P. L., \& Ye, F. (2012). A meta-analysis on the effects of service-learning on the social, personal, and cognitive outcomes of learning. Academy of Management Learning \& Education, 11(1), 927. https://doi.org/10.5465/amle.2010.0072 . 


\section{Appendix A}

\section{Statements Included in Pre- and Post-Test Assessments}

\section{Career Expectations}

There is more to the criminal justice system than law enforcement and corrections. The only career options for Criminal Justice majors are in law enforcement.* Criminal justice majors would make good contributors to service agencies.

\section{Service Agencies' Role}

Service agencies are not part of the criminal justice system.* Service agencies have no impact on the criminal justice system.*

\section{Statistics in the Criminal Justice System}

The criminal justice system needs to operate on evidence-based policies. I can use statistics to address a criminal justice problem. Statistics will not be helpful to me in my future career.* Statistics are key to conducting research on the criminal justice system. Statistics knowledge has no value in my future career.* This class provided knowledge that I will use in the future. Statistics are not necessary to determine effectiveness of policy changes. ${ }^{*}$ I would be at a disadvantage in the job market without statistics knowledge.

\section{Service-Learning Experience**}

I enjoyed engaging in a community project in this class.

I do not feel that my work in this class has made an impact on the community project.*

I took pride in my work on the community project from this class.

I do not think it is important to use my knowledge to assist my community.*

I feel that the community project helped me learn the class material easier.

The class material was more concrete because of the community project.

I feel that my time working on the community project was worthwhile.

*indicates that this agreement statement was reverse coded in the analyses.

**indicates that these statements were included only in the posttest assessment.

\section{Additional Questions}

What part of the community project did you enjoy the most?

Do you think there were any benefits to your participation in the community project as part of this class? If so, what were they and why? If not, why not?

What would you change about your participation in the community project? 


\section{Appendix B}

\section{Reflection Homework Assignment}

\section{Assignment Prompt}

After you attend the [service-learning engagement], you must write a 1- to 2-page reflection on your experience.

\section{Things You Should Discuss in Your Reflection}

- What did you think of the event and your experience? Of the people you interacted with?

- Why do you think this event is necessary in the first place? Is it effective? Why or why not?

- What is the one thing/message/idea that you gained as a result of participating in the event that you think will be the most applicable to your career?

- How do you think our collaboration is helping the people you interacted with and/or the service agency? What purpose will our results serve?"

\footnotetext{
About the Authors

Kimberley Schanz is an assistant professor of criminal justice at Stockton University. Kaela Giles was a graduate student at Stockton at the time of the study. She has since graduated. Correspondence concerning this article should be addressed to Kimberley Schanz at kimberley.schanz@stockton.edu.
} 